\title{
A Short Review on the Trend of Mobile Marketing Studies
}

\author{
doi:10.3991/ijim.v5i3.1581 \\ Mohammad Ismail ${ }^{1}$, Razli Che Razak2 \\ ${ }^{1}$ Universiti Teknologi MARA (UiTM), Malaysia \\ ${ }^{2}$ Universiti Utara Malaysia (UUM), Kedah, Malaysia
}

\begin{abstract}
The purpose of this paper is to elucidate the major classification of the research in mobile marketing. It provides the trend and common approach in mobile marketing research. The paper aims to highlight the significant area in mobile marketing research and the needs for further understanding of the mobile marketing definition and its phenomenon. This paper has significant implications in terms of understanding the classification and the mobile marketing focusing area. This is a general review based on selected approximately forty-six journal publications which are published between year 2005 until 2010 from selected journal. Based on the selected reviewed literatures, the consumers' adoption research only focuses on a few common areas. There is no agreement among the researchers on definition of mobile marketing and the conceptualization and phenomenon of mobile marketing remain unexplained. The value of this paper is that, it provides the fundamental guidelines for researchers on significant area to focus in the mobile marketing field and it also assists practitioners in indentifying the research trend and major classifications which will assist them in designing the product and services to the right target market.
\end{abstract}

Index Terms-Mobile marketing, Consumer Adoption, Consumer Acceptance

\section{INTRODUCTION}

Mobile phone penetration rate and mobile subscribers have tremendously increased. Mobile phone users worldwide have recorded 3 billion mark in late 2007, more than 4 billion in 2008 and are expected to increase more than 5.5 billion by end 2013 [1]. This scenario has increased the amount of people using mobile devices and accelerated the mobile phone to become most influential medium for marketing. Due to recent developments in mobile technology, most marketers are going into this data market in developing their content to reach larger audience and create a new source of revenue. In Asia Pacific alone, mobile data services are projected to grow from USD44 billion in 2008 to USD81 billion in 2012, contributing to $27.7 \%$ of total mobile revenues in 2012 [2]. The progress of mobile advertising revenue in the consumers' surrounding have turned the mobile marketing an impressive field to explore the research [3]. Even though there is a plethora of research in this area but the area of mobile marketing is still under development and has attracted considerable number of research among academicians in exploring this filed. Despite of the growing number of research, the academic literature in this area is still at an infant stage [3][4][5]. The purpose of this article is to provide an idea on the major classification of the re- search in mobile marketing, common focus of the research particularly on consumer's behaviour, common research approaches and reviews the theories that generally used in previous studies. The short review process has been considered on the approximately forty-six selected peerreviewed journal and proceeding papers published from year 2000 to year 2010 by considering the interest of mobile marketing study which was started in year 2000 and increasingly evolving in the year 2004. The researchers' interest towards empirical study on mobile marketing was started in the year 2005 and the topic is still growing interest recently. Finally, the paper is attained with the discussion which directs towards facilitates future research directions and we end up with the conclusion in the last section.

\section{Classification of Mobile Marketing Research}

There is no consensus on category or accepted classification of mobile marketing research among researchers[7]. In addition Leppäniemi et al. [7] in their review of mobile marketing research have classified mobile marketing research into three main categories namely consumer, business \& management and general category. However, Varnali and Toker [3] have classified mobile marketing research into four main categories namely theory, strategy, consumer behaviour and legal \& public policy. Both studies have revealed that the substantial number of publication of mobile marketing studies in consumer behaviour. Furthermore, recent trend of the studies is also focusing on consumer behaviour aspect. This development is in-line with the statement by Bauer et al. [21] which have stated that consumer acceptance is one the core issues in mobile marketing and the consumer acceptance has gained considerable importance as a field of research since the mid 1990s. By adapting the classification by Varnali and Toker [3], this paper has categorized mobile marketing research into four major categories but the study on reviews, definition and conceptualization of mobile marketing has been reclassified as general category.

\section{MAJOR CATEgORY OF MOBILE MARKETING RESEARCH}

Basically mobile marketing research has been classified under following categories:

\section{A. General}

This paper is classified by the general category which consists of studies related to definition and conceptualization of mobile marketing (e.g., [6], reviews studies (e.g., [7], state of the art studies (e.g., [3], etc. Tähtinen [6] for example has conducted a study in determining the 
definition and conceptualization of mobile marketing from both perspectives, academic and practitioners. Her study may help the researchers to understand the phenomenon of mobile marketing better than other terms used in describing the mobile marketing phenomenon. The study by Tähtinen [6] has argued that, when comparing the definition by academic and practitioners, mobile marketing looks like to be used to describe only one part of the marketing definition, namely the communication of value. Her study has proposed to use mobile marketing communication, which can differentiate mobile forms from any traditional non-mobile forms of marketing communication. However, the study on this category is still lacking and offers a large opportunity for researchers to explore.

\section{B. Strategy}

Basically this study is categorized on the research effort focusing on mobile media or channel and aid practitioners in their expedition to accomplish mobile marketing success (e.g., [8]. Another sub-area in this category is Mmarketing tools and applications. Barutçu [9] has revealed that there are seven mobile marketing tools which stand out as the crucial mobile marketing tools namely mobile advertising, mobile sales promotion, mobile entertainment services, location-based mobile services, mobile internet, mobile banking and mobile shopping. Such studies concern on how the tools will be used by consumers (e.g., [10] [11][12][13][14].

\section{Consumer Behaviour}

This category focuses on individual-level charateristics like demographics, perception, attitude towards mobile marketing and other factors that influence the adoption of mobile marketing. The trend of the studies is more towards consumer acceptance of mobile marketing by focusing on their behavioural intention. This category has grown interests among researchers (e.g., [15][16][17] [18][19][20][30].

\section{Legal and Political issues}

This category of studies consist of study on issues, trust and privacy in the mobile environment. Risk perception and trust play significant role in studying consumer adoption of mobile marketing. According to Bauer et al. [21] consumers' perceived risk has strongly influenced the consumer willingness to adopt mobile marketing. Consumer perceived risk is likely to become a determinant factor in affecting consumer's participation in mobile services [22]. On the other hand, in terms of consumer policy, the number of academic studies in this field is relatively low and future studies are very much needed [3]. Despite of a number of studies on perceived risk, there are still limited studies concerning on risk perception on mobile marketing. Very little studies are focusing on consumer perceived risk towards mobile marketing services (see [21][22][23].

The following diagram illustrates major category of mobile marketing research. Generally, there are four major categories of mobile marketing research with a few sub- areas. The selected studies concerning on category and the sub-topics from previous studies are figure out in Table I below.
TABLE I.

MAJOR CATEGORY OF RESEARCH IN MOBILE MARKETING

\begin{tabular}{|c|c|c|c|}
\hline No & Category & Sub Area & $\begin{array}{c}\text { Example of Selected Stud- } \\
\text { ies }\end{array}$ \\
\hline 1 & General & $\begin{array}{l}\text { Definition and } \\
\text { conceptualization, } \\
\text { Reviews }\end{array}$ & {$[3][7]$} \\
\hline 2 & Strategy & $\begin{array}{l}\text { M-Marketing } \\
\text { strategy, M- } \\
\text { marketing tools } \\
\text { and applications }\end{array}$ & {$[8][10][11][12][13][14]$} \\
\hline 3 & $\begin{array}{l}\text { Consumer } \\
\text { Behaviour }\end{array}$ & $\begin{array}{l}\text { M-Marketing } \\
\text { Acceptance, } \\
\text { adoption of M- } \\
\text { marketing, atti- } \\
\text { tude towards M- } \\
\text { marketing, per- } \\
\text { ception, M- } \\
\text { satisfaction and } \\
\text { loyalty }\end{array}$ & {$[15][16][17][18][19][20][30]$} \\
\hline 4 & $\begin{array}{l}\text { Legal and } \\
\text { Public } \\
\text { Policy } \\
\end{array}$ & $\begin{array}{l}\text { Trust,Privacy, } \\
\text { Legal and politi- } \\
\text { cal issues, }\end{array}$ & {$[21][22][23]$} \\
\hline
\end{tabular}

Source: Adapted from Varnali and Toker, 2010

\section{THE PRIOR STUdies APPROACH ON CONSUMER ADOPTION OF MOBILE MARKETING}

Generally, most of the previous studies are commonly focusing on a single areas such as mobile advertising, mobile services, mobile data services and mobile coupon, Several studies have examined consumers' attitudes towards mobile marketing (e.g., [5][9] [38]), consumer intention to use mobile data services ([24][25][26] 27]), mobile banking (e.g., [28][29][30]), mobile services (e.g., [31] [17][32][33]), adoption of mobile commerce (e.g., [34][23]) and consumers acceptance of mobile advertising(e.g., [16][12][19]). Another area which gaining more interests among researchers is mobile payment (e.g., [22][33][18]).

However, there are very limited studies focusing on the acceptance of mobile marketing (e.g., [35][36]). Moreover, mostly, the studies on mobile marketing research are concentrating on consumer's intention to use or behavioural intention rather than actual use. Based on the review of selected publication, only a few studies focusing on actual behavior (e.g., [30][37][38]). Prior studies in mobile marketing have provided strong justification for conducting the research on behavioural intention which indicates that behavioural intention is a strong predictor of consumers' behavior (e.g., [31][39][40][41]). Due to that trend, most of the current research is moving towards the same direction by focusing on consumers' behavioural intention (e.g., $[15][42][43][32])$.

\section{RESEARCH APPROACH}

Generally, previous studies have applied three approaches in carry out the research in mobile marketing which are personal survey, on-line survey and the combination approaches including interview. Even though each of the approaches has their own benefits and drawback but mostly the researchers applied personal survey approach in performing the research. In addition, personally administered questionnaires allow researcher to collect all the completed responses within a short period of time and it is inexpensive and efficient for collecting the data of large numbers of individuals at the same time [43]. Further- 
more, on-line survey is also getting more popular among researchers particularly in mobile service context. Recent studies have shown that online surveys have been utilized by a few researchers in conducting their studies (see [15][16][18][25][33][44].

Overall, previous studies do not limit to one approach only in conducting the studies especially in mobile study context. However, there are very limited studies uses mixed methodologies even though the approach also has the advantage. Driscoll et al. [44] reveal that "mixed method designs have the advantages when exploring complex research questions. The qualitative data provides a deep understanding of survey responses, and statistical analysis can provide detailed assessment of patterns of responses". Table II below demonstrates examples of the research approach employed by a number of previous studies.

TABLE II.

COMMON RESEARCH APPROACH

\begin{tabular}{|l|l|}
\hline $\begin{array}{l}\text { Source/Author } \\
\text { (Example of studies) }\end{array}$ & Methodology \\
\hline$[10][22][29][34][35] 36][38][51]$ & Personal Survey \\
\hline$[15][16][18][21][25][32][38][39]$ & Online survey \\
\hline$[23][30][42]$ & Mixed methods \\
\hline
\end{tabular}

\section{Theories Used by Selected Studies}

Several competing models or theories have been broadly used by researchers to predict the intention to adopt mobile services. The models comprise of the theory of reasoned action (TRA) [45], innovation diffusion theory (IDT)[46, theory of planned behaviour (TPB) [47], technology acceptance model (TAM) by [48], and decomposed theory of planned behaviour(DTPB)[49]. Among those theories, TPB, TAM and DTPB are frequently used by researchers in explaining the consumers' intention to adopt the mobile marketing services. This is constant with our prior discussion that numerous researchers concentrate more on consumer behavioural intention rather than the actual usage. Even though, it is very rare to have the studies that employ manifold theories but there are some studies that use multiple theories for study purposes comparison. The innovation diffusion theory [46] describes that five general attributes of innovations diffusion which have revealed to consistently influence consumers' adoption namely (relative advantage, compatibility, complexity,trialability and observability. Most of the previous studies do not fully utilise all the five key attributes of IDT but their studies have utilised some of the key attributes by integrating with other variables. Furthermore, Theory of Planned behaviour is also one of the theories that broadly use in technology acceptance studies. Surprisingly, based on selected reviewed publications, most of the studies that utilize TPB are more towards internet related. On the other hand, Technology Acceptance Model by [50] has been identified consist of two constructs namely perceived usefulness and perceived ease of use as the major determinants of individual attitudes toward the use of computer technology. Most of the studies that utilise TAM model will extend the theory with additional construct. Furthermore, Decomposed Theory of Planned Behaviour combines aspects of innovation diffusion theory [46] with aspects of the theory of planned behaviour [47]. DTPB suggests that attitude, sub- jective norm and perceived behavioural control will influence the intention to use technology. Previous studies that use DTPB also extend the model towards providing better understanding of behavioural intention to use. The theories also have been utilised in multi-disciplines area such as internet banking, mobile services and information technology related. There are very limited studies have utilised the DTPB in mobile services context (e.g., [10][25]).

\section{DISCUSSION}

Mostly, all the research unavoidably deals with study limitations. This study only considered a number of selected journals publication. Since the number of publications in mobile marketing keeps on increased, further research may consider focusing on other journals and more comprehensive analysis of the literatures.

Based on review of selected studies in mobile context, some issues of mobile marketing adoption have been highlighted. First, the consumer behavior studies towards mobile marketing are getting more interest among researchers but the academic literatures on mobile marketing are still at infant stage. More researches on this area are much needed. The explanation of mobile marketing phenomenon is still vague and it could be the main reasons why most of the researchers still do not reach agreement on the definition and classification of mobile marketing. Second, despite of growing number of research on mobile marketing services like mobile payment, mobile advertising, mobile data services, mobile banking, mobile commerce and mobile services, etc, the study on other mobile marketing services is keep on growing such as mobile learning (e.g., [51]), mobile ticketing, mobile booking, etc. The recent trend is most of the studies are using the terms by naming the category based on study context relevancy. The future study may propose the standardization of the mobile marketing services category so that other studies will use similar term and it can be generalized in future study on mobile marketing. Finally, the trend of the research approach in mobile marketing studies is more towards employ on-line survey. Even though personal survey has their advantages but on-line survey is getting trendy among the researchers. This is may be due to this kind of survey can reach globally, fast delivery and it is also convenient. The interesting part is the definition and conceptualization of mobile marketing phenomenon is still remaining unclear. Hence, this will provide a large opportunity for future discussion among researchers.

\section{VIII.CONCLUSION}

Prior studies note that there is no consensus among the researchers on definition of mobile marketing. In fact, the conceptualization and phenomenon of mobile marketing is still not fully explained. Researchers have defined and conceptualized the concept of mobile marketing according to their study context and situation. Hence, the selected review in this article might help the researchers at least to understand the major category of mobile marketing in understanding the definition of mobile marketing. The review of selected studies also may assist the researchers towards applying the research approach in their study by providing common research approach employed in previous studies. In all, despite of substantial amount of research in this field, the academic research in mobile marketing still provides a large research opportunities. 
There is still very scant research conducted in the area of trust, risk perception and policy. Varnali and Toker [3] reveal that research in the field of m-acceptance is still inadequate. Since the research on the consumer's acceptance of mobile marketing is still limited, therefore it is a need for researchers to devote more attention and to explore this field especially in different context of study.

\section{REFERENCES}

[1] Worldwide Mobile Market Forecasts 2009-2013. Retrieved October 222009 from http://www.portioresearch.com/WWMMF 09-13.html.

[2] MCMC (2010). Fact \& Figures (Statistics \& Record). Retrieved May 10, 2010 from http://www.skmm.gov.my/facts figures/ stats/index.asp.

[3] Varnali, A. and Toker, A. (2010), "Mobile marketing research: The state of the art". International Journal of Information Management, Vol. 30, pp. 144-151. doi:10.1016/j.ijinf omgt.2009.08.009

[4] Barnes, S. and Scornavacca, E. (2004), "Mobile marketing: the role of permission and acceptance", International Journal of Mobile Communication, Vol.2 No.2, pp.128-39. doi:10.1504/ IJMC.2004.004663

[5] Carroll, A., Barnes, S., Scornavacca, E. and Fletcher, K. (2007), "Consumer perceptions and attitudes towards SMS advertising: recent evidence from New Zealand". International Journal of Advertising, Vol.26 No.1, pp. 79-98.

[6] Tähtinen, J. (2006), "Mobile Advertising or Mobile Marketing. A Need for a New Concept. In: FeBR 2005 -Frontiers of e-Business Research 2005”, Conference Proceedings of eBRF, 152-164.

[7] Leppäniemi,M., Sinisalo,J. and Karjaluoto,H. (2006), “A Review of Mobile Marketing Research". International Journal of Mobile Marketing, Vol. 1 No. 1, pp. 30-40.

[8] Leppäniemi,M. and Karjaluoto,H. (2008), "Mobile marketing: from marketing strategy to mobile marketing campaign implementation". International Journal of Mobile Marketing, Vol. 3 No.1, pp. 50-61.

[9] Barutçu,S.(2007), "Attitudes towards mobile marketing tools: A study of Turkish consumers" . Journal of Targeting, Measurement and Analysis for Marketing, Vol.16, pp.26-38.

[10] Hsu, T.H.,Wang, Y.S., and Wen,S.C.(2006). "Using the decomposed theory of planned behaviour to analyse consumer behavioural intention toward mobile text message coupons". Journal of Targeting, Measurement and Analysis for marketing, Vol. 14 No. 4, pp. 309-324. doi:10.1057/palgrave.jt.5740191

[11] Komulainen,H.,Ristola,A., and Still,J.(2006), "Mobile advertising in the eyes of retailers and consumers - empirical evidence from a real-life experiment". Proceedings of the International Conference on Mobile Business (ICMB'06), Copenhagen, pp. 37-45.

[12] Merisavo,M., Kajalo, S., Karjaluoto, H.,Virtanen, V., Salmenkivi,S., Raulas, M., and Leppäniemi, M. (2007), "Emiprical study of the drivers of consumer acceptance of mobile advertising". Journal Of Interactive Advertising, Vol. 7 No. 2, pp. 41-50.

[13] Wong,C.C. and Hiew, P.L.(2005), "Diffusion of Mobile Entertainment In Malaysia Drivers and Barriers". World Academy of Science, Engineering and Technology, Vol. 11, pp. 135-138.

[14] Vlachos, P.A.and Vrechopoulos,A.P. (2008), "Determinants of behavioral intentions in the mobile internet services market". Journal of Services Marketing, Vol. 22 No. 4, pp. 280-291. doi:10.1108/08876040810881687

[15] Gu, J-C., Lee,S-C. and Suh,Y-H. (2009), "Determinants of behavioral intention to mobile banking". Expert Systems with Application, Vol. 36 No. 9, pp. 11605-11616. doi:10.1016/ j.eswa.2009.03.024

[16] Hanley, M., and Becker, M. (2008), "A Cell Phone Usage and Advertising Acceptance Among College Students: A Four-Year Analysis", International Journal of Mobile Marketing, Vol. 3 No.1, pp. 67-68.

[17] Lee, R.and Murphy,J. (2006), "The consumption of mobile services by Australian university students". International Journal of Mobile Marketing, Vol.1 No.1, pp.13-20.
[18] Schierz, G.P., Schilke,O. and Wirtz, B.W.(2010), "understanding consumer acceptance of mobile payment services: An empirical analysis". Electronic Commerce Research and Applications, Vol. 9 No. 3, pp. 209-216. doi:10.1016/j.elerap.2009.07.005

[19] Yang,C.C. (2007), "Exploring factors affecting consumer intention to use mobile advertising in Taiwan". Journal of International Consumer Marketing, Vol 20 No . 1, pp. 33-49.

[20] Zhang,J.and Mao,E.(2008), "Understanding the Acceptance of Mobile SMS Advertising among Young Chinese". Consumers Psychology \& Marketing, Vol. 25 No. 8, pp. 787-805.

[21] Bauer, H., Barnes, S., Reichardt, T. and Neumann M. M. (2005), “ Driving consumer acceptance of mobile marketing: A theoretical framework and empirical study".Journal of Electronic Commerce Research, Vol.6 No.3, pp.181-192.

[22] Chen, L.D. (2008), "A model of consumer acceptance of mobile payment". International Journal of Mobile Communications, Vol.6 No.1, pp. 32-52. doi:10.1504/IJMC.2008.015997

[23] Wu, J.H., and Wang,S.C.(2005), "What drives mobile commerce? An empirical evaluation of the revised technology acceptance model". Information\&Management, Vol. 42 No. 5, pp. 719-729. doi:10.1016/j.im.2004.07.001

[24] Hong,S.J.and Tam,K.Y.(2006), "Understanding the adoption of multipurpose information appliances: The case of mobile data services". Information Systems Research, Vol. 17 No. 2, pp. 162-179. doi: $10.1287 /$ isre. 1060.0088

[25] Hong,S.J., Thong, Y.L., Moon,J.Y., and Tam,K.Y.(2008), "Understanding the behavior of mobile data services consumers". Information System Frontier, Vol.10, pp. 431-445.

[26] Lu,J., Liu,C.,Yu,C-Y. and Wang,K. (2008), "Determinants of accepting wireless mobile data services in China". Information \& Management, Vol. 45 No.1, pp. 52-64. doi:10.1016/j.im.2007. $\underline{11.002}$

[27] Qi,J., Li,L., Li,Y. and Shu,H.(2009), "An Extension of Technology Acceptance Model: Analysis of the Adoption of Mobile Data Services in China". Systems Research and Behavioral Science. Vol. 26 No. 3, pp. 391-407. doi:10.1002/sres. 964

[28] Laforet,S. and Li,X. (2009), "Consumers' attitudes towards online and mobile banking in China".International Journal of Bank Marketing, Vol. 23 No.5, pp. 362-380. doi:10.1108/0265232 $\underline{0510629250}$

[29] Luo,X., Li,H., Zhang, J. and Shim, J.P. (2010), "Examining multidimensional trust and multi-faceted risk in initial acceptance of emerging technologies: An empirical study of mobile banking services". Decision Support Systems. Vol. 49 No. 2, pp. 222-234. doi:10.1016/j.dss.2010.02.008

[30] Jaradat,M.I.R. and Twaissi, N.M. (2010), “Assessing the introduction of mobile banking in Jordan using technology acceptance model", International Journal of Interactive Mobile Technologies.Vol 4(1),pp.14-21.

[31] Koivumaki,T., Ristola,A., and Kesti,M. (2006), "Predicting consumer acceptance in mobile services: empirical evidence from an experimental end user environment". International Journal of Mobile Communications, Vol. 4 No. 4, pp. $418-435$.

[32] Quan,S., Hao, C. and Jianxin, Y. (2010), "Factors Influencing the Adoption of Mobile Service in China: An Integration of TAM". .Journal of Computers, Vol. 5 No. 5, pp. 799-806.

[33] Verkasalo,H.(2008), "Dynamics of Mobile Service Adoption". International Journal of E-Business Research, Vol. 4 No. 3, pp. 40-63. doi:10.4018/jebr.2008070103

[34] Bhatti,T.(2007), "Exploring factors influencing the adoption of mobile commerce". Journal of Internet Banking and Commerce, Vol.12 No.3, pp.1-13.

[35] Rohm, A. and Sultan, F. (2006), "An Exploratory Cross-Market Study of Mobile Marketing Accepatance". International Journal of Mobile Marketing, Vol. 1 No. 1, pp.4-12.

[36] Sultan, F., Rohm, A.J. and Gao,T.(2009), "Factors Influencing Consumer Acceptance of Mobile Marketing: A Two-country Study of Youth Markets". Journal of Interactive Marketing, Vol. 23 No. 4, pp. 308-320. doi:10.1016/j.intmar.2009.07.003

[37] Pedersen, P. E. (2005), “Adoption of mobile internet services: An exploratory study of mobile commerce early adopters". Journal of Organizational Computing \& Electronic Commerce, Vol. 15 No. 3, pp. 203-218. doi:10.1207/s15327744joce1503_2 
[38] Lu,Y.,Zhou, T. and Wang,B. (2009), 'Exploring Chinese users' acceptance of instant messaging using the theory of planned behavior, the technology acceptance model, and the flow theory". Computers in Human Behavior, Vol. 25, pp. 29-39. doi:10.1016/j.chb.2008.06.002

[39] Karjaluoto,H., and Alatalo, T.(2007), "Consumers' attitudes towards and intention to participate in mobile marketing". International Journal Service Technology and Management, Vol. 8 No. 2/3, pp. 155-173.

[40] Kim,D.J., Ferrin,D.L. and Rao,H.R.(2008), "A trustbased consumer decision-making model in electronic commerce: The role of trust, perceived risk, and their antecedents", Decision Support Systems, Vol. 44 No. 2, pp. 544-564. doi:10.1016/j.dss.2007.07.001

[41] Wang, Y.S., Lin, H.H.and Luarn, P. (2006), "Predicting consumer intention to use mobile services". Information Systems Journal, Vol. 16 No. 2, pp. 157-179. doi:10.1111/j.13652575.2006.00213.x

[42] Kim, C., Mirusmonova, M. and Lee. I. (2010), "An empirical examination of factors influencing the intentionto use mobile payment". Computers in Human Behavior, Vol.26, pp. 310-322. doi:10.1016/j.chb.2009.10.013

[43] Kuo, Y.K. and Yen, S.N. (2009), "Towards an understanding of the behavioral intention to use $3 \mathrm{G}$ mobile value-added services". Computers in Human Behavior, Vol. 25, pp.103-110. doi:10.1016/j.chb.2008.07.007

[44] Driscoll, D.L., Yeboah,A.A.,Salib,A. and Rupert, D.J.(2007), "Merging Qualitative and Quantitative Data in Mixed Methods Research: How To and Why Not". Ecological and Environmental Anthropology, Vol. 3 No.1, pp.19-28.

[45] Fishbein, M. and Ajzen, I. (1975), Belief, Attitude, Intention, Behavior: An Introduction to Theory and Research, AddisonWesley, Reading, MA.

[46] Rogers, E. (1995), Diffusion of Innovations, 4th ed., Free Press, New York, NY.
[47] Ajzen, I. (1991), "The theory of planned behavior". Organizational Behavior and Human Decision Processes, Vol.5, pp.179211. doi:10.1016/0749-5978(91)90020-T

[48] Davis, F.D. (1989), "Perceived Usefulness, Perceived Ease of Use and User Acceptance of Information Technology". MIS Quarterly, Vol.13 No.3, pp. 319-339. doi:10.2307/249008

[49] Taylor,S., and Todd,P.(1995), "Understanding information technology usage: a test of competing models". Information Systems Research. Vol. 6 No. 2, pp.144-176. doi:10.1287/isre.6.2.144

[50] Davis, F.D., Richard P. Bagozzi, and P.R. Warshaw (1989), "User Acceptance of Computer Technology:A Comparison of Two Theoretical Models". Management Science, Vol. 35, pp. 9821003. doi: $10.1287 / \mathrm{mnsc} .35 .8 .982$

[51] Ismail,I.,Idrus,M.R., Ziden,A. and Rosli,M.(2010), "Adoption of Mobile Learning among Distance Education students in Universiti Sains Malaysia". International Journal of Interactive Mobile Technologies, Vol. 4(2), pp.24-28.

\section{AUTHORS}

Mohammad Ismail is with the Faculty of Business Management, Universiti Teknologi MARA (UiTM) Malaysia and currently doing his $\mathrm{PhD}$ at Universiti Utara Malaysia(e-mail: mohammadismail@perlis.uitm.edu.my).

Assoc. Prof.Dr Razli Che Razak is with the Othman Yeop Business School, Universiti Utara Malaysia, Kedah, Malaysia. Presently, he is attached as a Director at the Centre for International Affairs \& Cooperation (CIAC) (email: raz1152@uum.edu.my).

Received March $4^{\text {th }}, 2011$. Published as resubmitted by the authors June, $9^{\text {th }}, 2011$. 